\title{
Gene Therapy for LMNA-related Congenital Muscular Dystrophy (L-CMD) by Trans-Splicing
}

\author{
Feriel Azibani, ${ }^{*}$ Anne T Bertrand \\ From 1st French-Italian meeting on laminopathies and other nuclear envelope-related diseases \\ Marseille, France. 15-16 January 2015
}

LMNA-related Congenital Muscular Dystrophy (L-CMD) is a rare genetic disorder characterized by the onset of selective axial weakness and wasting in the first year of life with limited motor achievements, associated with multiple severe contractures and frequent respiratory failure requiring early ventilatory support. We identified heterozygous de novo mutations in LMNA, encoding lamins $\mathrm{A} / \mathrm{C}$, as responsible for this sub-group of CMD in which no therapeutic treatment is available[1]. Lamins $\mathrm{A} / \mathrm{C}$ are nuclear envelope proteins, ubiquitously expressed in all post mitotic cells, which play essential roles in the nucleus structure and in the regulation of gene expression. We generated the first Knock-In mouse model of L-CMD (KI-Lmna ${ }^{\text {delK32}}$ ) reproducing a LMNA mutation identified in L-CMD patients. Homozygous mice die within the first 3 weeks of life from striated muscles maturation delay and severe metabolic defects [2]. Heterozygous mice develop an isolated dilated cardiomyopathy and die by one year of age[3]. We aim to assess the possibility of LMNA-mRNA repair by spliceosome-mediated RNA trans-splicing (SMarT) as a potential therapeutic approach for L-CMD. This gene therapy strategy will allow inhibition of mutated LMNA transcript expression for the benefit of corresponding wild type transcripts. We developed 5'-RNA pre-trans-splicing molecules (PTM) capable of repairing the murine LMNA transcripts. Efficiency of these PTM was assessed in vitro in $\mathrm{C} 2 \mathrm{C} 12$ cells and in vivo using Adeno-Associated Virus (AAV) transduction in tibialis anterior of WT mice. We will now determine the ability of the best PTM to restore normal muscular phenotype, in vitro in KI myoblasts/ myotubes and in vivo after injection of AAV-PTM vectors in new born homozygous and adult heterozygous

\footnotetext{
* Correspondence: f.azibani@institut-myologie.org Sorbonne Universités, UPMC Univ Paris 06, INSERM UMRS974, CNRS FRE3617, Center for Research in Myology, Paris, France
}

mice. Histological and metabolic parameters will be monitored to evaluate the degree of phenotype rescue.

Published: 11 November 2015

\section{References}

1. Quijano-Roy S, Mbieleu B, Bonnemann CG, Jeannet PY, Colomer J, Clarke NF, et al: De novo LMNA mutations cause a new form of congenital muscular dystrophy. Annals of neurology 2008, 64(2):177-86.

2. Bertrand AT, Renou L, Papadopoulos A, Beuvin M, Lacene E, Massart C, et al: DelK32-lamin A/C has abnormal location and induces incomplete tissue maturation and severe metabolic defects leading to premature death. Human molecular genetics 2012, 21(5):1037-48.

3. Cattin ME, Bertrand AT, Schlossarek S, Le Bihan MC, Skov Jensen S, Neuber C, et al: Heterozygous LmnadelK32 mice develop dilated cardiomyopathy through a combined pathomechanism of haploinsufficiency and peptide toxicity. Human molecular genetics 2013, 22(15):3152-64.

\section{doi:10.1186/1750-1172-10-S2-O11}

Cite this article as: Azibani and Bertrand: Gene Therapy for LMNArelated Congenital Muscular Dystrophy (L-CMD) by Trans-Splicing. Orphanet Journal of Rare Diseases 2015 10(Suppl 2):O11.

\section{Submit your next manuscript to BioMed Central and take full advantage of: \\ - Convenient online submission \\ - Thorough peer review \\ - No space constraints or color figure charges \\ - Immediate publication on acceptance \\ - Inclusion in PubMed, CAS, Scopus and Google Scholar \\ - Research which is freely available for redistribution

() Biomed Central

(c) 2015 Azibani and Bertrand This is an Open Access article distributed under the terms of the Creative Commons Attribution License (http://creativecommons.org/licenses/by/4.0), which permits unrestricted use, distribution, and reproduction in any medium, provided the original work is properly cited. The Creative Commons Public Domain Dedication waiver (http://creativecommons.org/ publicdomain/zero/1.0/) applies to the data made available in this article, unless otherwise stated. 